\title{
Restriction of the Freedom of Movement under a High-Alert Regime
}

\author{
NATAL'YA P. ZARYAEVA \\ Voronezh institute of Advanced Training of Employees of the EMERCOM of Russia, \\ Voronezh, Russian Federation \\ ORCID: https://orcid.org/0000-0002-9496-2520, e-mail: nzaryaeva@yandex.ru \\ INNA L. OLIYNYK \\ Central Branch of the Russian State University of Justice, Voronezh, Russian \\ Federation \\ ORCID: https://orcid.org/0000-0001-8317-1128, e-mail: oliynyk_k_ap@mail.ru
}

\begin{abstract}
A bstract
Introduction: the article considers the high-alert regime and the associated restrictive measures related to the freedom of movement and introduced in connection with the threat of the spread of COVID-19. Aim: with the help of theoretical and legal analysis, we investigate the nature of the high-alert regime and the set of anti-epidemic measures implemented to prevent the spread of the COVID-19 pandemic; we also analyze the constitutionality and validity of restrictions on the right of an individual to freedom of movement and the proportionality of the restrictive measures imposed (quarantine, complete lockdown) in relation to the elderly, a particularly vulnerable population group. Methods: dialectical method, theoretical methods of formal and dialectical logic, comparative legal method, system-structural method, method of interpretation of legal norms, and others. Results: the research allows us to say that the set of terms related to the high-alert regime is not clearly defined from the legal perspective; moreover, there is no legally bounding limit to its operation (the period of its being in effect) and a mechanism for its direct implementation. We argue that the restriction of the freedom of movement for persons aged 65 and older is disproportionate in the context of their health protection interests. The article defines the following guarantees of restricting the exercise of the individual's right to freedom of movement: the legality and validity of temporary administrative and legal measures, the balance between private interests (preserving the protection of the legal status) and public interests (preventing the spread of the infection), specifics of the epidemiological situation, a set of timely measures aimed at providing particularly vulnerable categories of citizens with everything vital. Conclusions: we propose to interpret the restriction of the exercise of an individual's rights under a high-alert regime as a legally justified state intervention (through the adoption of proportionate restrictive measures) in the sphere of an individual's private autonomy in order to protect national security, public order, human life and health. We consider it necessary that legislation should specify the provisions defining the range of circumstances when a high-alert regime is to be introduced, the limits, boundaries and scope of additional powers of special actors, and the scope of possible discretion; the means to ensure this administrative and legal regime; the list of rights and freedoms subject to restriction when it is established, as well as the mechanism for their protection.

Keywords: citizens' rights and freedoms; freedom of movement; COVID-19 pandemic; high alert regime; restrictive measures; proportionality; elderly citizens (persons aged 65 and older.
\end{abstract}

12.00.14 - Administrative law, financial law, information law.

F or c it at i o n: Zaryaeva N.P., Oliynyk I.L. Restriction of the freedom of movement under a high-alert regime. Penitentiary Science, 2021, vol. 15, no. 2 (54), pp. 418-427. DOI 10.46741/2686-9764-2021-15-2-418-427.

Introduction

The individual, their life and health, honor and dignity, inviolability and security are recognized as the highest social value in the Russian Fed- 
eration. The rights and freedoms of man and citizen and the level of their provision determine the content and democratic orientation of the state's activities. The ability of a person to fully implement the rights and freedoms granted to them is due to the presence of a significant number of favorable conditions for their selfrealization as a specific person and a member of a democratic society.

At the same time, there are situations in which certain restrictions affecting the constitutional rights and freedoms of an individual and citizen may be imposed to prevent threats and ensure the safety and health of citizens. Thus, the COVID-19 pandemic has become one of the biggest challenges of the 21st century, affecting almost all aspects of human existence. The introduction of anti-epidemic measures (quarantine) aimed at minimizing the negative impact of coronavirus infection entailed temporary bans and restrictions on a number of basic rights of citizens. Special restrictions, expressed in the mode of complete self-isolation, affected the older generation. The related changes in the lives of the elderly have significantly reduced the level of communication and life activity, and increased anxiety and fear of social isolation.

Meanwhile, in the context of the pursuit of a legitimate goal, a number of important issues are resolved in the absence of a proper regulatory basis through public administration. The circumstances of the new reality dictate the need to analyze the protection of the rights and interests of elderly citizens and determine the proportionality of restrictive measures imposed under the high-alert regime.

\section{Main part}

Freedom is the ability to choose a particular model of conduct at one's own discretion. The boundaries of individual freedom in society are necessary for the organization of joint life. In a broad sense, freedom characterizes the general state of an individual, their social status. In a narrower, legal sense, it is characterized by the ability of an individual to perform certain specific actions within the limits established by law.

Human freedom is natural, inalienable and exists independently of the state and the law. At the same time, the state and the law are necessary to ensure the unhindered provision of individual rights and freedoms.

Freedom of movement of individuals is a fundamental concept of the legal system of any democratic state, because it is the degree of protection and the limits of the implementation of freedom of movement that serve as an indi- cator of the level of development of society as a whole, as well as its legal, economic and sociocultural institutions in particular.

The right to freedom of movement and free choice of place of residence is declared in Article 27 of the Constitution of the Russian Federation. This right refers to the person's fundamental freedoms that meet their individual needs. It reflects the degree of socially justified freedom of human conduct, their personal autonomy from state coercion, provided and protected by the state. As an important personal right, freedom of movement is closely linked to other groups of rights and freedoms.

Certain aspects of the right of man to freedom of movement, as well as the issues of restrictions on this right by state institutions, do not lose their relevance and continuously attract the attention of researchers [4-8; 12-14; 18-20]. Meanwhile, the problem of proportionality of restrictions as a means of legal influence during the period of the high-alert regime on the territory of Russia has not been investigated sufficiently.

The term "freedom of movement" is used in the scientific literature and legislation in a broad and narrow sense. In the broad sense, it includes the right to freedom of movement and free choice of place of residence within the state, the right to travel freely outside the territory of the state, and the right to return to the territory of one's state without hindrance. In the narrow sense, this is the right of a person to legally reside in the territory of the state, to move freely and unhindered in this territory, while taking into account the restrictions established by law. In our article, we shall talk about freedom of movement in its narrow sense.

The Constitution of the Russian Federation protects the citizen by restricting the public authority in the possibility of encroaching on the citizen's rights and the sphere of freedom. Constitutional restrictions and restrictions on constitutional rights are not identical concepts, since the Basic Law is a certain restriction on the activities of the state, state bodies, society and the individual. The grounds for the legal restriction of human and civil rights and freedoms enshrined in the Constitution of the Russian Federation are based on the principle of combining private and public interests. Thus, it can be concluded that it is not the right itself that is subject to restriction, but only its implementation.

The 1950 Convention for the Protection of Human Rights and Fundamental Freedoms 
provides a legal confirmation to what we have mentioned above: "There shall be no interference by a public authority with the exercise of this right except such as is in accordance with the law and is necessary in a democratic society in the interests of national security, public safety or the economic well-being of the country, for the prevention of disorder or crime, for the protection of health or morals, or for the protection of the rights and freedoms of others" (Articles 8, 10, 11).

The term "restriction" is interpreted as "a boundary, a limit, a border line; retention within a certain framework; a rule that restricts certain rights and actions; constraint by certain conditions; restriction of the scope of activity, narrowing of opportunities, etc." [1].

V.I. Kruss points out that "law in a broad sense - including its positive basis and legal practice - can show a wide variety of restrictions and classify them as elements of the legal system and means (functions) of the mechanism for ensuring law and order. However, before and in addition to such research and "achievements", the legal science developing on the basis of the constitutional legal understanding is primarily designed to answer questions about how and why legal restrictions are legitimate as well as permissible, acceptable and practically sound, i.e. constitutional" [11].

According to S.S. Alekseev, restriction is "an issue that concerns the scope of regulation, the limits of the rights available to individuals, which characterize the result of legal regulation". This result is achieved by narrowing the permissions, imposing new prohibitions, and additional positive obligations [3]. In other words, a legal restriction can act both in the form of a ban and in the form of a duty. A.N. Kokotov points out that any establishment of legal obligations or legal responsibility of individuals by a normative act is a direct or indirect restriction of the rights and freedoms of a person and citizen [10].

Restrictions are preventive and represent an exceptional measure, which is based on the law and which establishes permissible limits for an individual to exercise their rights and freedoms.

Certain infringements on the freedom of conduct caused by restrictive measures eliminate possible adverse implications for both the actors subject to restrictions and other persons. Legality is the basic criterion for restricting individual rights. The main function of such restrictions is to protect public relations in order to protect the foundations of the constitutional order, morals, health, rights and legitimate in- terests of other persons, to ensure the defense of the country and the security of the state.

The norms providing for the possibility of restricting the exercise of human rights and freedoms are contained both in national (the Constitution of the Russian Federation, Law of the Russian Federation 5242-I of June 25, 1993 "On the right of citizens of the Russian Federation to freedom of movement, choice of place of stay and residence within the Russian Federation") and in international regulations. At the same time, the methods of such restriction are determined directly by the norms of national legislation.

Among the existing international standards that provide for certain restrictions on freedom of movement and free choice of place of residence, we can single out the Universal Declaration of Human Rights of 1948 (hereinafter - the Declaration).

It is important to emphasize that the Declaration does not specifically define the possibility of restricting the right of an individual to freedom of movement and free choice of place of residence. It contains general provisions on restrictions that relate to all guaranteed rights and freedoms, and therefore, to the freedom of movement (Paragraphs 2 and 3 of Article 29). As stated in the Declaration, in the exercise of their rights and freedoms, everyone shall be subject only to such limitations as are determined by law solely for the purpose of:

- securing due recognition and respect for the rights and freedoms of others

- meeting the just requirements of morality, public order and the general welfare in a democratic society.

These rights and freedoms may in no case be exercised contrary to the purposes and principles of the United Nations.

Meanwhile, the restriction of freedom of movement is explicitly provided for in Article 12, Paragraph 3, of the International Covenant on Civil and Political Rights of 1966 (hereinafter referred to as the Covenant). The application of such a restriction requires "the existence of a threat to national security, public order, public health or morals or the rights and freedoms of others, and they should be consistent with the other rights recognized in the present Covenant". Also, the provisions on the possibility of restricting freedom of movement are contained in Paragraph 3 of Article 2 of Protocol no. 4 to the Convention for the Protection of Human Rights and Fundamental Freedoms of 1950. 
To date, there is no single approach to determining the list of principles of legal restrictions on human rights. For example, A.A. Podmarev, considering the constitutional basis for restricting the rights and freedoms of a person and a citizen, suggests highlighting such principles as the recognition of a person, their rights and freedoms as the highest value and the respect for the dignity of the individual; compliance and proportionality of restrictions to constitutional goals; the principle of equality; restriction of rights and freedoms on the social, racial, national, linguistic or religious grounds; the requirement for establishment of a certain legal form for making the restrictions binding; compliance of restrictions with international standards [17, p. 74.]. At the same time, among the whole variety of principles for restriction of rights and freedoms, the principle of legality should be considered the key one, since it provides an optimal balance of interests of the subjects of legal restriction.

The main features of legal restrictions include: 1) the narrowing of the content and/or scope of human rights and freedoms; 2) formal certainty of the restriction; 3) constitutionally defined purposes of the restriction; 4) possibility of imposing the restriction by the state.

Legitimate interference in the implementation of human rights is possible under certain conditions and grounds. Legal literature contains formal (an indefinite range of subjects in respect of which legal restrictions are applied, clarity, stability, predictability, accessibility, compliance with the adoption procedure, and a number of others) and material (preservation of the content of constitutional rights and freedoms of a person and citizen) grounds for restrictions.

Important conditions imposed on restrictive measures are as follows: 1) the possibility of restricting the exercise of the rights should be established by law; 2) restrictions in a democratic society should be objectively necessary; 3 ) the purpose of restrictions should be legitimate.

The practice of many countries shows that today it is the COVID-19 global pandemic that poses the greatest threat to human rights and freedoms, because in response to its spread, democratic states have imposed universal restrictions on the exercise of the right to freedom of movement, privacy, property rights and a number of other fundamental rights guaranteed by national constitutions and international treaties. This fact was noted by UN SecretaryGeneral Ant nio Guterres. In his report, he em- phasizes: "The COVID-19 pandemic is a public health emergency - but it is far more. It is an economic crisis. A social crisis. And a human crisis that is fast becoming a human rights crisis" [24].

It can be said that the global COVID-19 pandemic has posed serious challenges before state mechanisms for the implementation and protection of fundamental human rights and freedoms. At the same time, as emphasized by A. Burlacu, R. Crisan-Dabija et al., there have been no unified approaches to the response from the legislator and law enforcement in the world [25].

For example, the Czech Republic, Poland, Estonia and Norway introduced severe restrictions, including almost complete border closures. Another group of countries, which includes Germany, Switzerland and Denmark, introduced an abstract distinction between necessary and optional movement based on the reason for crossing the border. Those who live or work in the country, as well as those who are in transit, are usually allowed entry, while others are denied this right unless they can prove they have legitimate reasons to do this. Hungary and Lithuania have restricted the right of entry to persons from high-risk regions. Several countries have imposed severe restrictions on internal mobility, but have not systematically restricted access to the country (Italy, France, Belgium and Spain) [28].

In Ukraine, restrictions on the right to freedom of movement that have been introduced on the territory of the state so as to prevent the spread of infection are assessed by a number of researchers as unconstitutional and violating fundamental human freedoms [27].

I. Freckelton, when considering the decisions of the courts in Australia and Kenya (The Victorian Supreme Court judgment of Loielo v Giles (2020) VSC 722, Kenyan judgment of Law Society of Kenya v Mutyambai (2020)), points out that the decision to impose a curfew in order to reduce the spread of the COVID-19 virus was justified [23].

The Belgian Federal Government has taken a number of decisions to impose severe restrictions during the COVID-19 pandemic, which, as noted by T. Vansweevelt and F. Dewallens, are at variance with the current legislation on fundamental rights and freedoms (freedom of association and freedom of movement) [29].

J. Ramji-Nogales and I. Goldner Lang characterize the restrictions on freedom of movement imposed by the United States and the 
European Union as a serious challenge to fundamental principles, pointing out that the free movement of people without border controls is the main reason for the existence of the European Union, and the protection of persons fleeing persecution has been the main obligation of the United States since its founding. The implications of the closure, according to these researchers, put vulnerable groups of the population, which are allegedly protected by these domestic and international legal obligations, at serious risk [26].

It was the first time that the public authorities in Russia were faced with such a situation, and consequently, the country had no experience of management in such conditions. However, the necessity to contain the scale and reduce the spread of COVID-19 objectively required the competent authorities to regulate the regime with the subsequent adoption of emergency response measures.

Legal guidelines for the protection of the life and health of citizens in situations related to the spread of diseases in Russia are contained in the administrative legislation. The basic law here is Federal Law 52-FZ of March 30, 1999 "On the sanitary and epidemiological welfare of the population" (hereinafter - Federal Law 52). It establishes the term "restrictive measures (quarantine)", which should be understood as "administrative, health, veterinary and other measures aimed at preventing the spread of infectious diseases and providing for a special regime of economic and other activities, restricting the movement of people, vehicles, cargo, goods and animals".

Coronavirus infection (COVID-19) is included in the list of diseases that pose a threat to others. In such situations, there are several legal options for the government to respond to this disease: namely, the possibility of introducing a special legal state of emergency, a high-alert regime, and additional restrictive and anti-epidemic measures. These regimes differ in the degree of restrictive impact, which allows the state to choose the optimal response scenario.

Situations that require the introduction of special administrative and legal regulation are caused by the action of various factors. Professor I.L. Petrukhin proposed a classification that includes three main groups:

1. Natural disasters (earthquakes and volcanic eruptions, floods and tsunamis, hurricanes and tornadoes, severe and prolonged droughts or frosts, landslides, avalanches and mudslides, unusually intensive solar radiation, meteorites and other cosmic bodies).

2. Major disasters related to the operation of equipment, tests (explosions, wrecks of trains, ships, aircraft, fires that pose a special danger to the population and cause significant harm, disasters at nuclear power plants, other facilities for the use of nuclear energy for peaceful or military purposes, resulting in a significant increase in radiation, major disasters at factories, oil and gas pipelines, the discovery of burials of radioactive and toxic substances that pose a danger to the life and health of the population of the area, significant and stable excess of the maximum permissible concentrations of harmful substances in the air, water and land, which led to the shutdown of production and death of people).

3. Biological factors (epidemics, epizootics, irruption of locusts and other insect pests) [16, p. 46].

We agree with the researcher, who notes that these factors can create various dangerous situations both directly for the individual, and in general for society and the state; this entails the need for special administrative and legal regulation on the part of the authorities.

Administrative regimes within the framework of public administration can use specific legal means, forms and methods of public administration, restricting the rights and freedoms of citizens, imposing additional duties, and expanding the powers of public authorities.

The presence of a wide range of factors that provide the basis for the introduction of an administrative-legal regime complicates the construction of generalized administrative regimes.

As a rule, the introduction of special legal regulation is justified by the need to ensure protection of the individual and the state in situations related to social conflicts, natural, man-made and biological circumstances. An example of this can be found in the above-mentioned outbreak of COVID-19. Thus, taking into account the scale of the impacts of the pandemic, all the 85 constituent entities of the Russian Federation introduced a high-alert regime, which was contained in Article 4.1 of Federal Law 68-FZ of December 21, 1994 "On the protection of the population and territories from natural and man-made emergencies" (hereinafter - Federal Law 68). At the same time, in 44 constituent entities of Russia, this regime was recognized as a force majeure.

The high-alert regime provides for the possibility of introducing restrictive measures on the basis of "proposals, orders of the chief 
state sanitary doctors and their deputies by a decision of the Government of the Russian Federation or an executive authority of the constituent entity of the Russian Federation, a local self-government body, as well as by a decision of authorized officials of the federal executive authority or its territorial bodies, structural divisions under whose jurisdiction are defense and other special-purpose objects" (Part 2 of Article 31 of Federal Law 52).

The list of restrictive measures is contained in Paragraph 10 of Article 4.1 of Federal Law 68. In particular, on the basis of this law, the authorities have the right to restrict the access of people and vehicles to the territory where there is a threat of an emergency; to suspend the activities of organizations if there is a threat to the safety of the life of employees and other citizens; to implement other measures that do not restrict the rights and freedoms of man and citizen; create the necessary conditions for the prevention and elimination of an emergency situation and minimizing its negative impact. Also, administration bodies establish the procedure for using various reserves, including vehicles and warning devices, in case of an emergency.

The analysis has shown that the high-alert regime is different in terms of the severity and scope of legal restrictions, and is inferior to the measures provided for by the state of emergency and martial law.

At the same time, the present research allows us to say the terminological framework of the high-alert regime and the range of circumstances of its introduction are not defined clearly from the legal perspective; besides, there is no legally determined limit for the operation (period of existence) of this regime and the direct mechanism for its implementation. It seems that the absence of formally defined boundaries for the use of a special legal regime can lead to administrative arbitrariness and an imbalance in the system of separation of powers and cause a conflict of basic human rights provided for by domestic legislation and international law.

The constitutionality and validity of restrictions on the rights and freedoms of the individual is a relevant issue for any law-bound and democratic state. Without going into details, we note that researchers' approaches to this issue are different. The legal literature is dominated by the view that "there are no absolute rights and freedoms, all of them can be restricted", and "the exercise of subjective constitutional rights can be suspended in emergency situa- tions" [21, pp. 133-134]. This view is quite consistent with the provisions contained in Part 3 of Article 55 of the Constitution of the Russian Federation.

Experts predict that there can be new global pandemics and outbreaks of various socially significant diseases that pose a threat to others. In a crisis, in an extraordinary situation, the risks of disproportionate restrictions on human rights and freedoms are growing; therefore, additional attention should be paid to civic oversight.

The legal reality proves that there is a problem not only concerning the legal limits of the use of a special legal regime, but also concerning the proportionality of the scope of official duties of persons vested with public authority. Based on this, the legislative consolidation of the following measures take on a special meaning: the range of circumstances when the highalert regime can be introduced, the limits to this regime, a clear list of rights and freedoms that may be restricted, protection mechanisms in the event of violations of rights and freedoms, and the forces and means that ensure this administrative and legal regime.

In modern conditions, of particular scientific and theoretical importance is the clarity of the criteria that allow the law enforcement officer to determine the proportionality, validity and permissibility of the legal limits for restricting the exercise of human rights, including the right to freedom of movement,.

Special attention is drawn to elderly citizens, for whom special restrictions (bans) on movement and social communication are established in the regions. The authorities, pursuing preventive goals in the fight against the COVID-19 pandemic, have in fact made it much more difficult for people aged 65 and older to exercise their fundamental rights and freedoms.

The decisions of the authorized persons concerning the introduction of various restrictive measures (self-isolation regime) arouse fear and some misunderstanding among the population. Meanwhile, the constitutionality of locally adopted acts was considered by the Constitutional Court of the Russian Federation. Its legal position, set out in the resolution of December 25, 2020 no. 49-P "On the case of checking the constitutionality of Subparagraph 3 of Paragraph 5 of the resolution of the Governor of the Moscow Oblast "On the introduction in the Moscow Oblast of a high-alert regime for the management bodies and forces of the Moscow Oblast system for prevention 
and elimination of emergency situations and some measures to prevent the spread of a new coronavirus infection (COVID-2019) in the territory of the Moscow Oblast" in connection with the request of Protvino Town Court of the Moscow Oblast", indicates that the introduction of temporary restrictive measures, caused by the spread of coronavirus infection, does not contradict the Basic Law. The Constitutional Court of the Russian Federation "recognizes the right of citizens to movement, but specifies that in the event of a real public threat, residents must show "reasonable restraint" in exercising this right". The resolution notes that "the restriction of freedom of movement is not the same as the restriction of personal freedom".

It seems that in the context of the issue under consideration, it is necessary to discuss not the very possibility of introducing restrictive measures in the context of the global COVID-19 pandemic, but only the legal limits and proportionality of such restrictions, which protect the rights of elderly citizens from emasculation.

Let us consider this issue on the example of the provisions of the decree of the Governor of the Voronezh Oblast dated May 13, 2020 no. 184-u "On the extension of measures to ensure the sanitary and epidemiological wellbeing of the population in the Voronezh Oblast in connection with the spread of a new coronavirus infection (COVID-19)". Thus, according to clause 4.3, "citizens aged 65 years and older are obliged not to leave their place of residence or place of stay, actual location, including residential and garden houses located on garden land plots". At the same time, the provisions of the decree define exceptional cases, including "seeking emergency medical care, and other direct threats to life and health; following to the nearest place of purchase of goods, works, services, walking pets at a distance not exceeding $100 \mathrm{~m}$ from the place of residence (stay), waste removal; following to the place (from the place) of work(service), performance of official duties, assistance to persons in need of the care of others; visits to state bodies in response to their call; visits to forensic institutions, lawyers, notaries; visits to medical, pharmacy, and veterinary organizations".

As can be seen from the example, restrictive measures are not an absolute ban, since they allow the movement of elderly citizens in the presence of valid circumstances. At the same time, a special restrictive measure - the obligation not to leave the place of residence - in the territory of the region tends to be prolonged, which cannot but cause some concern. The problem is seen in the fact that these measures are extended from March 2020, and this significantly complicates the implementation of not only freedom of movement, but also other personal rights.

This situation is typical of the majority of constituent entities of the Russian Federation. In fact, the introduction of complete lockdown for this category of persons is not accompanied by adequate support measures, which does not exclude problems associated with an unbalanced diet (or its lack), safe access to money, medicines, maintaining physical health, and social assistance.

Many citizens aged 65 and older live alone or at a distance from their relatives, so complete isolation (even with a justified purpose) creates additional difficulties for them. Thus, the intensification of the digitalization process during the COVID-19 pandemic demonstrated that the majority of older people have difficulties accessing digital platforms and lack the necessary skills to use digital communication tools. When implementing and actively using modern digital solutions, we should not miss the fact that due to age (due to loss of vision, hearing or other age-related features), even the usual means of communication are not available for many people.

The analytical note "COVID-19 and human rights", prepared by UN experts, highlights the particular vulnerability of the elderly, indicating that in many countries "older people are exposed to discrimination on the basis of age, as well as in the provision of medical care; neglect and domestic violence; isolation without access to basic services" [22].

It is clear that in the context of the COVID-19 pandemic, the state promptly responded to the existing legal realities and introduced new mechanisms for the implementation of human rights. While such measures are crucial for ensuring the safety of the country's population, it is clear that they should not exacerbate social exclusion and worsen the health status of this category of citizens.

Supporting and preserving the quality of life of older people in conditions of self-isolation is an interdisciplinary problem [2; 15].

Thus, according to a number of experts in the field of medicine, long-term restrictions associated with the possibility of free movement in the fresh air (motor activity), and stress are a much more serious threat to human life than COVID-19 itself. Therefore, in this matter, it is 
extremely important to pay attention to the balance, which consists in weighing the special restrictive measures imposed for a long period (complete self-isolation) and the fundamental freedoms and health of elderly citizens.

No doubt, the restrictive measures cannot deny the essential content of fundamental freedoms, namely, exclude their exercise. For example, it is proven that the infection does not spread in the open air (except in cases of close contact of a healthy person with a sick person or a carrier of the virus), therefore, the ban imposed on elderly citizens for walking in parks and squares (in the open air) for the reasons of preventing the spread of infection cannot be compatible with the essential content of the law. In these circumstances, we consider the following measures to be adequate: limiting the maximum number of persons aged 65 and older who are gathered together, establishing the social distance between them and setting the duration of their communication.

Thus, this particularly vulnerable category of citizens should be protected not so much by imposing tougher restrictions on freedom of movement, but mainly by providing them with adequate supportive measures and social protection (access to social support and basic necessities for elderly citizens who are in quarantine or self-isolation, a proportionate and non-discriminatory approach to restricting freedom of movement, for example, the allocation of separate time periods for their visits to shops, pharmacies or park areas).

We cannot but mention the significant assistance provided by volunteers to older people. The movement "MyVmeste" [We are together] is in action since the introduction of anti-epidemic measures. It was organized by the AllRussian People's Front, "Medical Volunteers" and the Association of Volunteer Centers.

We agree with N.A. Kovtun, who notes that "volunteerism is a new form of social service for the population" [9, p. 44]. In particular, in the Voronezh Oblast, there are mobile teams, including activists of the regional branch of the All-Russian non-governmental movement "Victory Volunteers", representatives of student teams and the regional Resource Center for Support to Volunteerism. Previously, the volunteers take an educational course to help the elderly in the fight against coronavirus on the Skill Cup platform.

However, unfortunately, the assistance provided to elderly citizens by both social workers and volunteers is insufficient. Older people still need access to social benefits and other protection measures (especially if they do not possess digital technologies), which means that both the state and society should take more efforts to provide timely support to this category of citizens, do everything possible to preserve their rights and dignity, during the period of self-isolation as well.

\section{Conclusions}

The above suggests that ensuring human rights is more or less a challenge for every democratic state, as the public health crisis in the context of the COVID-19 pandemic is rapidly turning into a socio-economic and human rights crisis.

We believe that the restriction of the exercise of individual rights under a high-alert regime can be understood as a legally established state intervention (through the adoption of proportionate restrictive measures) in the sphere of an individual's private autonomy in order to protect national security, public order, human life and health.

The scale and severity of the COVID-19 pandemic demonstrate the necessity and appropriateness of the high-alert regime in Russia; the introduction of this regime is aimed at achieving the public benefit of curbing the spread of the virus and protecting the health of the entire population.

Meanwhile, the current legal uncertainty of the special legal regime hinders administration of the law and requires the legislator to introduce necessary and relevant adjustments to administrative legislation. The following aspects are subject to consolidation: the accuracy and certainty of the terminological framework; the range of circumstances under which a high-alert regime is introduced, the time limits of the specified regime; a clear list of rights and freedoms subject to restriction; protection mechanisms in case of violation of rights and freedoms; the scope of additional powers of special actors, the limits of possible discretion; the list of forces and means that ensure this administrative and legal regime.

It is quite difficult to set forth a prospect of any global pandemic. One thing is clear: the situation with COVID-19 has entrusted the public authorities (within the framework of governmental policy) with not only operational, but also systemic tasks aimed at improving the protection of older citizens. We should emphasize that citizens aged 65 and over make up a significant part of Russia's population. Therefore, it is crucially important to maintain a balance between 
private (preserving the protection of the legal status) and public (preventing the spread of infection) interests in the decisions taken. When determining this balance, the basic goal is to achieve such a consistency of these interests that would make it possible to protect the value of the highest order. Ensuring the public interest at the expense of the private one is possible only if this contributes to ensuring constitutional democracy.

Thus, when restrictive measures associated with a high-alert regime are introduced, the limits and conditions for restricting the rights and freedoms of citizens 65 years of age and older must be observed:

- a balanced assessment of the epidemiological situation;

- the significance, proportionality and validity of the temporary administrative and legal measures carried out;
- a clear time frame for the restrictions;

- a set of adequate measures aimed at providing this category of persons with everything vital.

The society has to adapt to the circumstances that have emerged during the period of the high-alert regime, but only if balance is observed in terms of the restrictive measures taken. The balance, which includes the criteria of proportionality, validity and permissibility of legal restrictions, will act as a kind of legal barrier to the risks of arbitrary restriction of fundamental human rights and freedoms.

We hope that the attempt to study certain problematic aspects of the special legal regime will serve as a scientific tool for further improvement of legislation in relevant areas and the practice of its application.

\section{REFERENCES}

1. Avak'yan S.A. Konstitutsionnoe pravo Rossii. Uchebnyi kurs: uchebnoe posobie: $v 2$ tomakh [Constitutional law of Russia. Training course: textbook: in 2 volumes]. 5th edition, revised and supplemented. Moscow: Norma: INFRA M, 2014.

2. Zhdanov R.I., Khabibullin I.M., Khammatova E.F., Aidarov V.I., Zhdanova S.I., Dvoenosov V.G., Khairullin R.N. Active longevity: long-term clinical observation. Rossiiskii zhurnal geriatricheskoi meditsiny=Russian Journal of Geriatric Medicine, 2020, no. 4, pp. 339-349. DOI 10.37586/2686-8636-4-2020-339-349. (In Russ.).

3. Alekseev S.S. Obshchie dozvoleniya i obshchie zaprety v sovetskom prave [General permission, and general prohibitions in Soviet law]. Moscow: Yuridicheskaya literatura, 1989. 288 p.

4. Aleshkova I.A. Pravo na svobodu peredvizheniya: voprosy teorii i praktiki: dissertatsiya na soiskanie uchenoi stepeni kandidata yuridicheskikh nauk [Right to freedom of movement: theory and practice: Candidate of Sciences (Law) dissertation]. Moscow, 2005. 172 p.

5. Gromyko A.A. Coronavirus as a factor in world politics. Nauchno-analiticheskii vestnik Instituta Evropy RAN=Scientific and Analytical Herald of the Institute of Europe RAS, 2020, no. 2, pp. 5-13. Available at: https://cyberleninka.ru/article/n/ koronavirus-kak-faktor-mirovoy-politiki (accessed February 25, 2021). (In Russ.).

6. Duraev T.A. Svoboda peredvizheniya v doktrine Konstitutsionnogo Suda Rossiiskoi Federatsii: avtoreferat dissertatsii na soiskanie uchenoi stepeni kandidata yuridicheskikh nauk [Freedom of movement in the doctrine of the constitutional Court of the Russian Federation: Candidate of Sciences (Law) dissertation abstract]. Saratov, 2007. 25 p.

7. Ivanova M.A. Problems of the realization of the citizens' rights to freedom of movement, choice of location and residence. Mariiskii yuridicheskii vestnik=Mari Law Vestnik, 2015, no. 1 (12), pp. 159-161. (In Russ.).

8. Kazantseva E.V. Realization of the right to freedom of movement. Uchenye zapiski Krymskogo federal'nogo universiteta imeni V. I. Vernadskogo. Yuridicheskie nauki=Scientific Notes of V.I. Vernadsky Crimean Federal University. Legal Sciences, 2019, vol. 5 (71), no. 4, pp. 350-357. (In Russ.).

9. Kovtun N.A. Evolution of legislative regulation of social services in Russia. Nauka i obrazovanie: khozyaistvo i ekonomika; predprinimatel'stvo; pravo i upravlenie=Science and Education: Economy; Entrepreneurship; Law and Management, 2020, no. 7, pp. 40-44. (In Russ.).

10. Kokotov A.N. Konstitutsionnoe pravo Rossii: kurs lektsii [Constitutional law of Russia: a course of lectures]. Moscow: Prospekt, 2007. 296 p

11. Kruss V. I. Restrictions of human rights and legal restrictions: problems of doctrinal differentiation. Yuridicheskaya tekhnika=Juridical Technique, 2018, no. 12. Available at: https://cyberleninka.ru/article/n/ogranicheniya-prav-chelovekai-pravovye-ogranicheniya-problemy-doktrinalnogo-razgranicheniya (accessed March 3, 2021). (In Russ.).

12. Limonova N.A. The problem of the abuse of rights in the field of freedom of movement. Rossiiskaya yustitsiya=Russian Justice, 2014, no. 6, pp. 56-58. (In Russ.).

13. Mirolyubova S.Yu. Pravo na svobodu peredvizheniya v predelakh Rossiiskoi Federatsii: konstitutsionno-pravovoi aspect [The right to freedom of movement within the Russian Federation: constitutional and legal aspect]. Moscow: Statut, 2013. $154 \mathrm{p}$.

14. Ozel' V.I. Constitutionality of restrictions on human rights and freedoms in quarantine conditions. DICTUM FACTUM, 2020, no. 2 (7), pp. 43-51.

15. Petrosyan V.A. A new vector of protecting the interests of older people in self-isolation: from pathogenic to salutogenic. Meditsina. Sotsiologiya. Filosofiya. Prikladnye issledovaniya=Medicine. Sociology. Philosophy. Applied Research, 2020, no. 4, pp. 143-145. (In Russ.).

16. Petrukhin I. L. The legal regime in the conditions of social disaster. Gosudarstvo i pravo=State and Law, 1993, no. 2, pp. 46-50. (In Russ.).

17. Podmarev A.A. Konstitutsionnye osnovy ogranicheniya prav i svobod cheloveka i grazhdanina v Rossiiskoi Federatsii: dissertatsiya na soiskanie uchenoi stepeni kandidata yuridicheskikh nauk [Constitutional foundations of the restriction of 
human and civil rights and freedoms in the Russian Federation: Candidate of Sciences (Law) dissertation]. Saratov, 2001. $235 \mathrm{p}$.

18. Potemkina O.Yu. The impact of COVID-19 on freedom of movement and migration in the European Union. Nauchnoanaliticheskii Vestnik Instituta Evropy RAN=Scientific and Analytical Herald of the Institute of Europe RAS, 2020, no. 3, pp. 88-94. (In Russ.).

19. Slavna O.V. Regulatory regulation of restriction of freedom of movement in the conditions of emergency situation in Ukraine. Bulletin of the Penitentiary Association of Ukraine, 2020, no. 2 (12), pp. 30-37.

20. Sorokina E.A. State anti-epidemic policy: Swedish experience in countering coronavirus. Vestnik Sankt-Peterburgskogo universiteta MVD Rossii=Bulletin of Saint Petersburg University of the Ministry of Internal Affairs of Russia, 2020, no. 3 (87), pp. 42-53. DOI: 10.35750/2071-8284-2020-3-42-53. (In Russ.).

21. Khabrieva T.Ya., Chirkin V.E. Teoriya sovremennoi konstitutsii: monografiya [Theory of the modern constitution: monograph]. Moscow: Norma, 2005. 319 p.

22. COVID-19 and Human Rights. We are all in this together. Available at: https://www.un.org/sites/un2.un.org/files/ human_rights_and_covid19_russian.pdf (accessed February 3, 2021). (In Russ.).

23. Freckelton I. COVID-19 curfews: Kenyan and Australian litigation and pandemic protection. Journal of Law and Medicine, 2020, vol. 28, no. 1, pp. 117-131.

24. Guterres A. We are all in this together: human rights and COVID-19 response and recovery. Available at: https:// www.un.org/en/un-coronavirus-communications-team/we-are-all-together-human-rights-andcovid-19-response-and (accessed February 3, 2021).

25. Burlacu A., Crisan-Dabija R.A., Covic A., Raiu C., Mavrichi I., Popa I.V., Crespo M.L. Pandemic lockdown, healthcare policies and human rights: Integrating opposed views on COVID-19 public health mitigation measures. Reviews in Cardiovascular Medicine, 2020, vol. 21, no. 4, pp. 509-516.

26. Ramji-Nogales J., Lang I.G. Freedom of movement, migration, and borders. Journal of Human Rights, 2020, vol. 19, no. 5, pp. 593-602.

27. Zolka V., Tsarenko O., Kushnir I., Tsarenko S., Havrik R. The impact of the pandemic COVID-19 on the human right to freedom of movement. European Journal of Sustainable Development, 2021, vol. 10, no. 1, pp. 376-388.

28. Thym D. Travel bans Europe: a legal appraisal. US Immigration and Ayslum Law and Policy. Available at: http:// eumigrationlawblog.eu/travel-bans-in-europe-a-legal-appraisal-part-i/ (accessed February 3, 2021).

29. Vansweevelt T., Dewallens F. Healthcare law and the COVID-19 outbreak in Belgium. Medicine and Law, 2020, vol. 39, no. 2, pp. 131-150.

\section{INFORMATION ABOUT THE AUTHORS}

NATAL'YA P. ZARYAEVA - Candidate of Sciences (Law), associate professor at the Department of Special Training, Voronezh Institute of Advanced Training of Employees of the EMERCOM of Russia, Voronezh, Russian Federation. ORCID: https://orcid.org/0000-0002-9496-2520, e-mail: nzaryaeva@yandex.ru

INNA L. OLIYNYK - Candidate of Sciences (Law), Associate Professor, associate professor at the Department of State and Legal Disciplines, Faculty of Training Specialists for the Judicial System, Central Branch of the Russian State University of Justice, Voronezh, Russian Federation. ORCID: https://orcid.org/0000-0001-8317-1128, e-mail: oliynyk_k_ap@mail.ru 